\title{
A reflection on Attar Neyshabouri's Masnavi illustration
}

\section{Una reflexión sobre la ilustración de Masnavi de Attar Neyshabouri}

\section{Eshrat Ishan Agha}

PhD Student, Department of Persian Language and Literature, Mashhad Branch, Islamic Azad

University, Mashhad, Iran

ORCID: https://orcid.org/0000-0001-6867-0631

\section{Reza Ashrafzadeh}

Professor, Department of Persian Language and Literature, Mashhad Branch, Islamic Azad

University, Mashhad, Iran

ORCID: https://orcid.org/0000-0002-5392-9273

\section{Majid Taghavi}

Professor, Department of Persian Language and Literature, Mashhad Branch, Islamic Azad

University, Mashhad, Iran

ORCID: https://orcid.org/0000-0003-2965-5708

*Correspondence

Email: r.ashrafzadeh@iaubir.ac.ir
Cite as:

Ishan Agha, E., Ashrafzadeh, R., \& Taghavi, M. (2021). A reflection on Attar Neyshabouri's Masnavi illustration. Propósitos y Representaciones, 9 (SPE2), e64. Doi: http://dx.doi.org.10.20511.pyr2021.v9nSPE2.964 


\section{Summary}

Image or imagination, ink and paste are the main themes of poetry, and since the end of the sixth century, which is one of the most fertile periods of Persian literature, the poets of this period freely imposed many poetic fantasies on Persian literature, And for centuries, with various acquisitions, they were influential in the poetry of the poets of the generations after them (Shafiee, 1999, pp. 404 and 405). The use of abstract and difficult philosophical and philosophical concepts in mystical poetic works has been common in various ways and forms in the form of allegorical anecdotes, educational stories and moral sermons. And provides various perspectives for the study and evaluation of such works. Attar Neyshabouri also believes that the world is a picture of the beauty of truth that reflects all the beauties of the beloved in itself, and one can easily see the attributes of beauty in the world and creatures. Since Attar Neyshabouri is both a poet, a Sufi and a sage, his works can be examined from three mystical, philosophical and literary perspectives. Attar Neyshabouri's works, such as his Masnavi, are among the mystical works in which the poet has used legal and philosophical themes and terms in accordance with the subject. He has also benefited greatly from the elements of imagery in order to make his words effective. In this discourse, the method of illustration and the method of using the elements of imagination, such as simile, metaphor, permission, irony, have been evaluated.

Keywords: Illustration, Masnavi, Attar Neyshabouri

\section{Resumen}

Imagen o imaginación, tinta y pasta son los temas principales de la poesía, y desde finales del siglo VI, que es uno de los períodos más fértiles de la literatura persa, los poetas de este período impusieron libremente muchas fantasías poéticas sobre la literatura persa. durante siglos, con diversas adquisiciones, fueron influyentes en la poesía de los poetas de las generaciones posteriores (Shafiee, 1999, págs. 404 y 405). El uso de conceptos filosóficos y filosóficos abstractos y difíciles en obras poéticas místicas ha sido común de diversas maneras y formas en forma de anécdotas alegóricas, historias educativas y sermones morales. Y aporta diversas perspectivas para el estudio y evaluación de dichos trabajos. Attar Neyshabouri también cree que el mundo es una imagen de la belleza de la verdad que refleja todas las bellezas del amado en sí mismo, y uno puede ver fácilmente los atributos de la belleza en el mundo y las criaturas. Dado que Attar Neyshabouri es poeta, sufí y sabio, sus obras se pueden examinar desde tres perspectivas mística, filosófica y literaria. Las obras de Attar Neyshabouri, como su Masnavi, se encuentran entre las obras místicas en las que el poeta ha utilizado temas y términos jurídicos y filosóficos de acuerdo con el tema. También se ha beneficiado enormemente de los elementos de las imágenes para que sus palabras sean efectivas. En este discurso se ha evaluado el método de ilustración y el método de utilizar los elementos de la imaginación, como el símil, la metáfora, el permiso, la ironía.

Palabras clave: Ilustración, Masnavi, Attar Neyshabouri

\section{Introduction}

Sheikh Farid al-Din Mohammad Attar Neyshabouri is one of the greatest Persian language poets in the second half of the sixth century and the first quarter of the seventh century AH. Before examining the images and themes of Attar Neyshabouri's Masnavi, now realized that Attar should be considered the spirit of practical and romantic mysticism, reviving and cultivating lofty and pure meanings that a mystic and a principal like him can understand and transmit them, he has renounced the world and the mafias, and his whole existence has become a soul full of knowledge and cognition. Although conveying concepts that are in the realm of personal experience is a very difficult task, but our enlightened old man has skillfully and artistically 
composed and expressed these concepts in the form of a story and sometimes in a verse.

According to this theory, Dr. Shafiee Kadkani has equated the two terms "imagination" with the word "image". Therefore, what is referred to today in the science of expression as (metaphor, irony, imagery and simile) is the same imaginary that is presented differently from the language of first-rate poets. "Poets, in different ways in nature and its elements, capture the connection between the outside and inside world and its relation to their feelings and emotions and this mental capture of the poet, in the sense of nature and man, and this mental effort of his to establish a relationship between man and nature, is what we call imagination and image, and the spiritual element of poetry, in all languages and in all eras, is the same imagination and the way of capturing the poet's mind, in showing material and spiritual facts, and the main background of poetry is the various and infinite forms of these mental possessions" (Shafiee Kadkani, 1979: 2).

Words and images (in illustration) are responsible for the narration of concepts and subjects and are in fact signs and emirates of meanings. Shadows are examples and signs of intentions, and according to their ability to express, they tell a story about the subject in a way and manner. Concepts and purposes will not find true manifestation in it. In the art of illustration, the audience's understanding of the work of art becomes original and the illustrator, based on the knowledge of the characteristics of the social or age group and the situations of the audience, creates the visual text for the spoken or written text and that is why the illustrator, like the painter, cannot have artistic experiences independent of the subject and the subject. Thus, illustration creations are bound to the audience and the subject.

One of the reliable criteria in the critique and analysis of the illustration of literary works is the study of rhetorical techniques used in it. Rhetorical sciences include meanings, expressions, and innovations that are collectively called the imaginative sciences of Islamic literature, there are sciences that discuss the methods, techniques and artistic tricks of a literary work and it is by using these three knowledge's that the difference between ordinary language and literary language can be revealed. Of the three sciences, rhetoric and novelty are mostly concerned with the imaging arrays of imagination and verbal music of speech. Hence, the poet, for the beauty of his words, makes more use of imaginary forms and alternative tricks.

Imagination, which is the subject of the discussion of the knowledge of expression, is one of the tricks of illustrating speech. In other words, the poet makes his speech more artistic by using arrays of simile, metaphor, metaphor and irony. So "if a poet or artist uses imaginary images, he is trying to express something that is impossible or very difficult to say in ordinary words or with common sense" (Jung, 1993: 66). For this reason, the presence of imagination is a necessary element in poetry. But, is just paying attention to the element of imagination enough for poetry? Or why the poetry of one poet is more enduring than that of another, even though both have used the element of imagination, and or why the poetry of one poet is more enduring than that of another, even though both have used the element of imagination, and can poetry have the value of creating images by using only the element of imagination? Shafiee Kadkani answers all these questions in one sentence and writes: "The value of an imagination in the emotional burden of that imagination is and the imagination that is free from emotion, no matter how beautiful, does not reach eternity" (Shafiee Kadkani , 2001: 90).

"The poet's mental capture of the concept of nature and man and his mental effort to establish a relationship between man and nature is what we call imagination or image" (Shafiee Kadkani, 1996: 17). Every poet and writer may use different forms of expression to express his purpose with the help of the power of imagination, all of which are collectively referred to as imaginary forms; thus, the art of expression is a discussion of the image and the various forms of their arrangement. Since imaginary forms are an integral part of thought, in mystical language, images directly form meaning and are in no way an element separate from meaning so that they can be added to it and adorn it. The image in mystical poetry has a structural and fundamental nature, and since the language of mysticism is a language that is concerned with the connection of the part to the whole and the disappearance of the appearance inwardly and perishing for survival, images of contrast are the most appropriate and communicative type of imagination.

Among the categories of rhetoric, simile is the most widely used element. In order to make his mystical experiences tangible and sensory, Attar has benefited a lot from similes, his trick in 
using this literary array is to change and capture. In other words, he has sometimes captured images taken from others in order to breathe a new spirit into them. He does not suffice with the use of stereotyped images, but, using poetic creativity, combines images or compensates for the duplication of images with literary industries and by combining and integrating in imaginary forms, it adds to the stereotypical image, argument or pristine thought.

One of the characteristics of Attar's similes is the dynamism and movement of his images and descriptions of nature as if he lives with nature and he spends his life with them, and the images are specific to the poet's natural and direct feeling and although the main elements of the similes are matter and nature, some images of science terms, especially astronomy, can be seen in his images.

The extent of his knowledge in this area. On the other hand, he is a creative poet who creates beautiful meanings and praises the great ones with artistic descriptions, and in this way, like other poets, he uses virtual language. He has also made extensive use of elements of imagery to make his speech effective. In virtual language, the poet goes beyond the realm of lexical language and creates a new image by relying on rhetorical arrays. "The term imagery is used for all applications of virtual language, in this sense, the image is any virtual use of language, including all rhetorical devices and devices, such as similes, metaphors, metaphors, allusions, and so on." (Fotouhi, 2010: 45). Islami Nodoshan describes Attar as more of a thinker than a poet, and believes that he had a very strong spirit that paid more attention to thought in his poems than to the appearances and ornaments of his poetry, and that is why in his poems, There is a sea of meaning, the German Orientalist Helmut Ritter called his book on Attar the "Sea of Life". (Islami Nodooshan, 2004: 113).

The design and transmission of complex mystical concepts from different angles undoubtedly has many problems, among them is the lack of understanding and understanding of these concepts by the reader, the abuse of the mystics through the mystical experiences of others and the use of these words as a weapon against the speaker. The way that Attar and other mystics have considered to overcome these problems is to convey these concepts in the form of allegories, stories, fantasies, allusions and symbolic allusions, so that only those who are familiar with mystical and spiritual concepts are the confidants of the mystics' lofty thoughts and ideas, and the incompetent and strangers do not enter it, so that the fear of life and the danger of distorting the thought disappear.

In this article, the author has studied illustration with announcement in Attar Neyshabouri's Masnavi (Elahinameh, Asrarnameh, Mosibatnameh and Mantiq Al-Tair) while decoding the theme, he also described the type of image and imaginary forms. Attar Neyshabouri is the best representative of the imaginary forms of the sixth century speakers in the field of nature and his images are often external and terrestrial, accessible and tangible, and arise from the poet's private experiences from childhood to the creation of the image with a realistic and realistic view of nature and its elements. An issue that is very important in creating imaginary faces. The material of his images is nature in all its breadth and cultural, religious, Quranic and mythological elements with a detailed, extensive, complex, fresh and living structure of nature.

\section{Research background}

Entering any topic and research requires knowing the history and background of that research, therefore, familiarity with past researches and researches that are related to the research topic, the prelude to the wider research in which the author has stepped.

Mankind's use of imaginary forms (similes, metaphors, allusions, mysteries, and allegories) since the creation of man, and that he taught him the truth of all names, that is, the true identity of things, in other words, introduced him beyond the appearance of beings. The language of symbolism and mystery dates back to when humans carved images on the walls of caves, or when they lit fires as a sign to inform others of their place or a particular situation; as black smoke was the symbol of unrest and white smoke was the symbol of calm. Even today, codes, ironies, similes and metaphors can be seen throughout human life; as the image of a skull with two bones crossed is a symbol of danger. Either the traffic signs are a sign of a specific concept, or when a father affectionately addresses his son as a dady, he has used some kind of permission. These specialized terms are not limited to the field of literature and difficult books. 
Language is one of the living and dynamic aspects and phenomena of society, it is always evolving with intellectual changes and social, political and economic developments and its inner meanings and applications, of which imagination is a part, also change. That is, just as the people and poets of each age and period have a specific language system, their system and intellectual system, depending on the prevailing values in the society of their age, is more or less specific and related to the same period. As a result, the purpose and manner of using these forms and the frequency of their use in different periods are different. Regarding the illustration and illustration of Attar's Masnavi in particular, few researches and articles have been written so that each of the researchers, due to the holistic view of the subjects, has misled the research results. But the author intends to play a clear result of the art of illustration of this famous poet by focusing on this innate talent and special feature of Attar.

\section{Methodology}

One of the objectives of this research is to present various images of intellect in the common and idiomatic sense using illustration tools in Attar Neyshabouri's Masnavi, according to the research that has been done in this field, no independent research has been done in this field so far and since Attar Neyshabouri has been one of the great poets in Persian literature and illustration has a high place in Persian poetry, it seems necessary to study his poems from this perspective. This research is a library method and a descriptive-analytical method. First, all the verses are extracted and divided according to the type of expression based on the science of expression. In order to conduct this research, the Masnavi of Farid al-Din Attar Neyshabouri Elahinameh, Asrarnameh, Mosibatnameh and Mantiq al-Tair have been used. References to the verses of this research are based on the bit number and the name of the work.

\section{Basics of illustration and image creation}

Every human being has a set of spiritual powers, which constitute his existential capacity. Among these forces, the imaginative power has a privileged position. Because man is called an artist by the creation of a work of art and by the invention of industry.

the question is: in what process is beauty visibly displayed in a work of art and How the imagination "forms" for concepts and meanings and how are verbal connotations able to activate the imaginative power of their audience in such a way that the audience is able to imagine the artist's imaginary forms beyond words, Or create imaginary forms through the words and structure of the literary text. How are concepts without "forms" embodied and objectified in illustration, and how is the painter able to play the role of meanings? Different stimuli of the imagination, based on different goals and objectives, perform activities in the imagination, based on the capacity of the imagination. We know that the nature of these activities is different. Based on his understanding of beauty and art, the artist finds a relationship with his imagination that the truth and essence of art and beauty in this relation will be the origin and source of the work of art. Philosophers, scientists, and artisans have a different relation to the imaginary, and the products of such a relation are either science or industry or the intellectual worlds that interpret the world. The origin and form of expression (artistic form) and the end of the work of art are different from the origin and nature of the end of industries with pleasures. Imagination becomes functionalist in the face of artistic intuition and the invention of applied appliances in industry, and in art, the nature of illustration and artistic imagination and the semantics of literary texts and illustration for the story is the subject of this article. The imagination is able to embody imaginary and creative forms of the world of art and beauty, and to the extent that this power is perfect, it creates more original imaginary forms in the world of art, and it reveals a higher perfection of the truth of beauty in a work of art. The imagination is the source of the study of imaginary forms in the art world. Research on the relationship between this power and art and its function in illustration, which is an art related to literary texts, it opens an important and controversial chapter in the field of theoretical studies of art. Illustration in art and its realization in a work of art is based on the creative imagination of the artist. The image is literally equal to the institution of the image, it means the image, the copy, the shape and the entanglement of the world of the mind and the object , it is used to express mentalities and in the term in the meaning and definition of poetry: "It is a kind of weaving and 
a kind of image" (Jahez, 1999: J 132/2). In Persian, the image in the sense of image was first used by Shafiee Kadkani in the book Sore Khiyal. "The collection of what is presented in Islamic rhetoric in the science of expression can be considered as the subject and background of the image because its various permissible forms and similes are the main pillars of poetic imagination "(Kadkani, 2007: 9).

Fotouhi sums up the term image as follows: "Any virtual use of language includes all rhetorical devices and arrangements, such as similes, imagery, metaphors, allusions, allegories, symbols, etc." (Fotouhi, 45: 2006). In his book, Fotouhi quotes Farbank in expressing the complexity as well as the wide range of concepts and terms of image and illustration as follows: "The ambiguity and complexity of this term is that it refers to all literary industries, from rhyme, verse and weight to simile, metaphor and symbol, and is even used to analyze and discover the meaning of poetry" (Ibid: 37).

"The image is the ringing of two things from two different worlds, by words at a certain point, these two things or several things are possible, it has emotional or intellectual capacities and also usually belongs to different times and places that are gathered together by the image. The power of illustration is the most important part of the power of imagination "(Braheni, 1965: 6). It seems that Reza Braheni's definition of image is the best and most comprehensive definition. The description of the Skeleton from the image of the poem is also accurate and acceptable: "The image in the poem is an expression that gives life to the mental forms resulting from the poet's sensory perceptions, in other words, it makes the reader feel that he sees, touches, smells or hears something differently."(Skeleton, 105: 1996).

Artistic illustration has a nature independent of taste and liking of habits and associations and relative and credit affairs and is a fact that the artist receives it with a spiritual and transcendent intuition, and creates his work of art according to the form of the same truth. Artistic creation takes place in the "artistic form", and the work of art is a tangible form of beauty created by the artist's imagination. Words in literature and literary texts, whether poetry or fiction, realize concepts and meanings with imaginative formations. Verbal connotations are able to activate the imagination of the audience so that the imagination of the audience sees the imaginary forms of the artist beyond the words, or create an imaginary image in his imagination based on his preconceptions and historical horizons.

Clear poetry is the thought of poets and thinkers that flows from the source of the poet's soul and is engraved on the page. Thought and thinking that is a reflection and result of countless perceptions and images that the poet has placed in his mind about nature and the world around him. Shafiee Kadkani in his book "Imagination" considers the field of resurrection of words with the main observance of brevity and beauty "(Shafiee Kadkani, 1996; 13).

Because poetry is the manifestation of the word, it creates the innermost and most capable forms of imagination in the listener and the reader. In this pure art, certainly these forms, without resorting to tangible and objective illustration like painting and visual arts, in a special way, reconstruct the image of the world in the imagination of the audience, the higher the rhythmic foundations of poetry, the deeper there must be in the realm of the listener's imagination. Imagination, then, is the illustration that the poet creates with the help of words through language, reach your sensory experience in relation to the world of meanings to those imaginary manifestations, and in fact, the artist can travel to the realm of truth when what he creates reflects the truths of the universe and his imaginary forms reflect the meaning of the universe. Past poets, "despite all the attention they have paid to the importance of forms of imagination in poetry, have spoken less about the role of imagination in the structure of poetry, and the reason for this silence should be sought more in the way they think about poetry and its meaning. Because they have paid more attention to the appearance and form of poetry and the essence of poetry has been less attention to them. The importance of imagination in the construction of poetry has been less talked about, but those who have a logical and philosophical view of concepts have considered the element of imagination as the main essence of poetry." (Shafi'i, 1996; 7).

Although Iran's greatest imaginative poets have remained silent on the matter, but this negligence is not due to the fact that the great poets of Iran did not have a wide and pure imagination and or less used, the way in which the elements of imagination are used in the 
works of the great Persian poets in the centuries of Iranian literature proves the claim that, the most artistic, eloquent and imaginative poets and writers of the world have emerged in the infinite range of Iranian poetry and literature, poets such as Rudaki, Khaghani, Nezami, Attar, Rumi and Hafez have been.

The illustrator illustrates the most beautiful and expressive imaginary forms received from the text of the story. That is, he must first select the appropriate image forms for illustration, based on his "preferences," thus, the "taste" of the illustrator plays an important role in visual expression. The illustrator embodies his interpretation of the text, and the artist's imagination is the source of meaning. The artist's intentions, which are the stimulation of inner feelings and the communication of the subject (subject), will stimulate the imagination, and the series of meanings that are the subject of art will be realized in the container of imagination.

Illustration of the meanings and concepts of the story and narrative is based on receiving the artist's image from literary texts. Illustration for a literary text has principles and rules that change based on each visual and literary tradition and the situation that the text has in front of the audience and the audience in front of the text, and it is not possible to formulate a fixed rule and a permanent principle in the illustration of literary texts and implement it as a single instruction. Man is a questioning being, and there have always been questions that have been the source of perfection and have developed human understanding.

The question is: in what process is beauty evident in the work of art, and imagination, how it "forms" for concepts and meanings and how are verbal meanings able to activate the imaginative power of their audience in such a way that the audience is able to imagine the artist's imaginary forms beyond words? Or create imaginary forms through the words and structure of the literary text. How do concepts without "forms" become embodied and objectified in illustration, and how is the painter able to play the role of meanings?

Different stimuli of the imagination, based on different ends and goals, realize actions in the imagination based on the capacity of the imagination. We know that the nature of these activities is different. Based on his understanding of beauty and art, the artist finds a relationship with his imaginative power that the truth and essence of art and beauty in this relation will be the origin and source of the work of art. Philosophers, scientists, and craftsmen have a different relationship with the imaginary and the products of such a relation are either science, or industries, or the intellectual worlds, which interpret the world. The origin and form of expression (artistic form) and the end of the work of art are different from the origin and nature of the end of industries with pleasures. Imagination takes on a functionalist nature in the face of artistic intuition and the invention of applied devices in industry, and not in art, the pictorial nature and the artistic imagination and semantics of literary texts and illustration for the story are the subject of this article.

\section{Image creation in literature}

Poetry and literature are undoubtedly dependent on the world of human imagination and it does not belong only to what he observes or perceives with his sensory perceptions; hence, poetry and literature are an infinite realm whose borders are shaped by the imagination and the mental power of its creator.

"Illustration in poetry is a kind of artistic creation by which the poet gives life to colorful words and objects and it puts an emotional burden on them and with the help of these images, it creates a new world "(Zarrinkoob, 1988: 190); Imaginary: It is a force of the human soul, which is the architect of the imaginary world. The work of art receives its nature from the world of imagination, because the work of imagination is the creation of form and it is based on the artist's intuition that imagination creates artistic forms. Art comes from the world of imagination, and philosophy from the world of reason. The artist illustrator illustrates the most beautiful imaginary forms of literary texts, and based on the "preference of aesthetic forms" creates imaginary images of the fictional text, and the narrative of his own image. Words in literature and literary texts, whether poetry or fiction, realize concepts and meanings with imaginative formations. Verbal connotations are able to activate the audience's imagination in such a way that the audience's imagination sees the artist's imaginary images beyond words or creates an imaginary image in the imagination based on its presuppositions and historical 
horizons. The illustration of the meanings and concepts of the story and narrative is based on the artist's perception of literary texts. Illustration for a literary text has principles and rules that change based on each visual and literary tradition and the situation that the text has in front of the audience and the audience in front of the text, and it is not possible to formulate a fixed rule and a permanent principle in the depiction of literary texts and implement it as a single instruction. Man is a questioning being, and there have always been questions that have been the source of perfection and have developed human understanding. Creation in this sense means creating the most beautiful visual image of a literary text. The painter creates illustrations based on the aesthetic structure of the text. Otherwise, the illustration of the story will be based on personal perceptions and aesthetics of the painter.

The presentation of the image alone is not the goal; rather, unless a strong thought and feeling is included beyond the image, we will not have an efficient and effective image; as Hamid Zarrinkoob believes in the mission of the image, beyond the image itself, in his collection of articles and says: "A poetic image leaves a deep impression when there is human thought and feelings behind it, and discovery and creativity" (Zarrinkoob, 1988: 196). If the literary text intends to convey a message, the illustrator of the text must also follow the communicative aspect of the text, and his image, in addition to the imaginative aspects, must convey the message of the text as an image. Just as a literary text is interpreted by reading, so the pictorial text is interpreted according to the meanings of the image and the meanings (image reading). The image should never contradict the meaning of the text, although it is possible to provide visual interpretations of the text and to express different aspects of the interpretation of the text in the form of images, because concepts in literary and pictorial texts are not inherent in words or images, audiences interpret these texts based on their own mental backgrounds.

The artistic text (whether literary or pictorial) is like a material for the interpretation of the audience, and credit, painting, actualized forms of the meanings of the text are in the minds of the interpreters. With the proviso that interpretation cannot be anti-text, but interpretation is the result of mixing the horizon of expectations and understanding of the interpreter (audience) with the text, in the present. As a result, different understandings of the text will lead to different interpretations, which move in the circle of general meanings of the text. Because the audience will be able to understand the text by anticipating the semantic totality of the text. What is original in literary texts and illustrations of literary texts is the subject and the beauty of the structure of expression is at the service of meanings and concepts and narration and story. As a result, in the arts where the communicative aspect becomes original, the audience's perception will also have a decisive aspect in the evaluation of the work of art. Forms of artistic expression in literature, and illustration for it, based on knowing the recipient of the message (audience) from all possible aspects, wider the scope of this knowledge by the writer and illustrator, the greater the success of communicating the purpose and conveying the message.

\section{Illustration in Masnavis of Attar Neishabour}

As each society has its own system of thought and language, each poet also has his own linguistic features and the way he uses his own literary adornments, words and phrases; So that the words and interpretations in the poetry of current and first class poets have a special identity. Therefore, the images and themes that they create using these words, in some cases it is personal and the result of their intellectual creativity, in particular, to use words in the form of literary images for specific purposes; As Nasser Khosrow used poetry as a means to propagate the Ismaili religion, and Attar and Rumi as a means to understand mystical knowledge and human suffering. The face of Attar in his poems is the face of a moral teacher, mystic and original that all his efforts have been to show how to behave, stay away from the world and the people of the world, headed by kings and the rich. This forces him to use symbolic language; because to express mystical themes that are on the one hand in the realm of personal experiences and feelings and on the other hand its issues cannot be expressed directly and recklessly, the poet has to use cryptic and metaphorical language, although he expresses supernatural issues in the form of stories of people, persons and allegories. Also to use historical examples to extend to oppressive rulers, or to portray the lives of religious leaders and mystics indirectly in the form of stories or the use of imaginary forms; to awaken their dormant conscience in such a way that 
it does not endanger itself. Therefore, the use of imaginary forms to express mystical concepts, political and social issues, first of all in the field of mysticism makes the issues more tangible and removes rich mystical concepts from strangers, In such a way that only the nightingales of the garden of mysticism who have experienced these states themselves understand it and the secret of the friend is not revealed, secondly, in the field of political issues, it protects the poet from danger as a safeguard; because the poet can completely hide his original meaning in case of criticizing the opponents and when he is afraid of death, and know the purpose of expressing issues in the form of code and metaphor of the appearance of words. So the rules and regulations that the science of expression offers and that it has a specific definition for each form of imagination; Perhaps in general, it applies to the poetry of non-first-rate poets. In that seeker of thought, with constant effort, and through the worlds of horizons and souls, he reaches the knowledge of his soul as the first step in the knowledge of truth, and human perfection, in order to be able to continue his journey with strength in the next steps, of course, Attar considers its explanation subject to obtaining permission from God. In expressing his opinion about Attar's right, he believes that the seeker will not realize his essence unless he travels in himself, and when he realizes that the people of the holy world are nothing more than a subordination to his precious existence and essence:

Until you travel to yourself, when will you reach for yourself?

If you find your way to all the saints, you will find yourself constantly

But until it was in the journey itself, you did not really think so

(Attar, 198: 2013)

Although Attar's confrontations serve content and meaning, they do not lose their creative aspect of imagery, and through this element, Attar's poetry is filled with literary arrays. So that examples can be found for most of the pictorial patterns found in the books of expression and novelty.

\section{Illustration based on the science of expression}

Every poet and writer, with the help of the power of imagination, may use different forms of expression to express his purpose, all of which are collectively referred to as imaginary forms; thus, the art of expression is a discussion of the image and the various forms of their arrangement. Since imaginary forms are an integral part of thought, in mystical language, images directly form meaning and are in no way an element separate from meaning, so that they can be added to it and adorn it. The image in mystical poetry has a structural and fundamental nature and since the language of mysticism is a language that is concerned with the joining of the parts to the whole and the disappearance of the outward inwardness and perishing for survival, images of contrast are the most appropriate and communicative type of imagination. With a brief look at the historical course of Persian poetry, we see that the use of metaphors, imagery, allusions and intensive similes (rhetorical similes) is increasing along with social changes and a direct relationship with the spirits and thoughts of people of each era. As it has been said, the types of imaginary forms are: simile, metaphor, permission and irony, which is a brief definition of each or witness of examples of Attar Neyshabouri's Masnavi in the order of frequency:

\section{Simile}

Simile as one of the pillars of virtual language plays an important role in illustration. The first and simplest method of illustration and the most appropriate way to express meaning is used in the poetry of order and even ordinary speech. In simile, the word is used in its true sense, and is often used to exaggerate praise or blame or the expression of the nature and truth of something unknown to something more known and familiar. Thus, simile is the first manifestation of the poet's imagination, the main theme of which is exaggeration and imagination. In Attar's Masnavi, the simile of the most frequent is the tool of illustration, meanwhile Attar's imaginary forms are not useless of this poetic element, examples of which are given. The simile and metaphor blossom and highlight the common element between the two things, and thus, by the connection between the phenomena, they make it certain to be understood, and they give one thing, and sometimes several ideas and aspects, what is the same between different words and opinions in the definition of simile, that is, similitude is like doing one thing; But the scholars 
have defined it as follows: "The simile is to compare one thing to another in industry" (Homayi, 1371: 1992). Or "The term simile in the science of expression means likening something to something, provided that the likeness is based on a lie or at least a lie, which is, accompanied by exaggeration, as a result, it can be said that a metaphorical sentence is a sentence that does not seem to be correct, causes astonishment, and no one believes in its contents. (Shamisa, 2005: 32). For example:

Her watery lips were thirsty. Narcissus flower had thousands of stickers. (Attar, 2006/1425).

Narcissus, which is just a flower, is turned into an eye in addition to a flower and the garnet, which is a precious and shining stone, is likened to a lip.

\section{Summary of simile:}

If the quasinym is not mentioned in the simile, it is called a summary of simile.

Be like cotton black hair, No head, no cotton in your hat. (Asrarnameh, 2007/1568)

"Black hair" (similar) is likened to "cotton" (similar to) and the face is not mentioned as (white). He gave the last fuel to the bread and the dog, an old man followed him because of the wind. (Ibid., 2007/1990)

"Old" (similar) is likened to "wind" (similar to) in terms of speech.

Anchorite sat down and left the ground, it was like hair from the moon.(Mantiq al-Tair, 2004/1932)

The afflicted lover is similar to "anchorite ", similar to "like", and "hairy", and the quasi-face that should be received from similar to "hair". The choice of such a word "hair" as similar to, shows the great power of the poet's imagination.

\section{Detailed of simile:}

If the quasi face is mentioned in the simile, it is called in detail.

Because the sea is constantly changing, because men are constantly thinking. (Asrarnameh, 2007/1926)

In the first scene, "you" is similar and the sea is "similar to" that he considered the change of the sea as a quasi-face with this difference, change and transformation for the sea, the apparent meaning of "turbulence and turbulence" and for you, spiritual transformation and evolution, is desired. In the second stanza, according to the poet, "you" is similar to men and "similar to", and in thinking, he mentions being a quasi-face, which is a detailed analogy.

Rotating chicken fills the way, it hits the door like a ring. (Mantiq al-Tair, 2004/26)

In this verse, "rotating chicken" is similar and "because" is a metaphorical device and "ring" is similar to and "heads" is a quasi-face.

\section{Expressive simile:}

If the quasi face and the adjective are removed, that is, both emphatically and concisely, it is called an expressive simile.

Near the fish day and night in his alley, He waited for the sun on him.(Mantiq al-Tair, 2004/1933)

The fire of your love became like a torch, Make a series of madmen. (Mosibatnameh, 2007/2536)

Jihad and war with the soul are more difficult than war and material and physical strife. To provide a favorable environment for turning to infidelity and accepting the religion of fear.

Like a chicken, soul falls down full of feathers, See yourself applied in water. (Asrarnameh, 2007/1091)

Because the soul belongs to God and must return to it, mystics and poets have likened this practice to a bird-like flight that flies from its original destination and then returns.

\section{Metaphor:}

The word means to borrow. "Metaphor" or "metaphoa" is derived from the Greek word "metaphora", which itself is derived from "mata" meaning "beyond" and "phereix" meaning (take). The term refers to a specific category of linguistic processes in which aspects are transferred from one object to another. In a way, the second object is spoken of as the first object" (Hawks, 1998: 11). Metaphor, then, means using one word for the sake of resemblance, instead of another.

Metaphor can be divided in different directions; if the metaphor is compatible (mild) or not, it is 
divided into three categories: absolute metaphor (abandoned), metaphorical (abstract) and nurtured metaphor (secret) (Kazazi, 1989: vol. 138).

Attar, with the help of his talent and creative power, uses metaphor to show his hidden findings, and with his breadth of thought and deep vision, he creates metaphorical images, which the reader is bound to admire. Despite the wide range of applications, this array is evident throughout Attar's Masnavi. In other words, despite the fact that metaphor is one of the most effective and imaginative tools in expressing Attar's sensory and objective experiences, therefore, we will suffice to mention the most important of them.

Another point that should be stated in the way of describing Attar is that his art of depiction, both in his poems and in his Masnavi, is generally alien to praise, therefore, if the sun is similar to, or a metaphor is placed on someone, this person has either a religious or religious face, such as:

It was because Mustafa was a prophet, because there was another in his shadow In the light of the eastern sun, because it slows down the server light. (Attar, 1994, 19)

Here the sun, a metaphor for the blessed existence of the Prophet (PBUH) is used:

Who is the right and the prophet is the guardian, which is the good character of Hussein bin Ali The sun is the sky of knowledge, That Mohammad face and Haidar stiff. (Same / 37)

Here, the metaphorical sun is used for Imam Hussein (AS). And Attar says that after all creatures; one must see the Lord of beauty, who lies in every particle of creation.

Because the sun of knowledge shines, from the sphere of this excellent path

The brain sees from within, not from its skin, He sees no particle but his friend. (Attar, 2009/392)

\section{Single explicit metaphor:}

Whenever in the word, similar to, is mentioned with one of the similar (metaphorical) mildness, it is called single.

It is not an encomium with the Lord of Insight, The house of the breast and the month of creation. (Asrarnameh, 2007/165)

"Breast and moon" are explicit metaphors of the Prophet. "Creation" is one of the similar things to. « الو لا لما خلقت الافلاك "Bith

Sometimes with that month, you make a celebration sometimes you paid for it. (Mantiq al-Tair, 2004/4357)

"Moon" is an explicit metaphor of "beloved", but synonyms such as "celebrating with him" and "with a look on his face" are related to the similarity, which is a single metaphor with similar mention along with similar mildness.

Because Pimber came from Ascension, Aisha said that $\mathrm{O}$ sea of secrets

Hear the secret, hear the truth, with my heart in the middle of not one precedent. (Mosibatnameh, 2007 / 498-9)

The conversation is between Aisha and the Prophet (PBUH), Both bits of words such as "Aisha" and "secret" as well as the letter " $\mathrm{O}$ " which is specific to human beings, are all deleted from similar tenderness, that is, it is the Prophet (PBUH) who causes the audience to recognize the explicit metaphor of the single with a little reflection and care in words.

He had put a stone in his mouth, that gem did not spread his tongue. (Elahinameh, 2008/307)

In the virtues of Abu Bakr, the first caliph of the Muslims, it is said that he puts stones in his mouth to speak less, according to this practice and the allusion to it, the word "gem" is an explicit metaphor.

\section{The explicit metaphor of the sign:}

It is a metaphor in which quasi-metaphor (similar to) are mentioned.

Until the child gets used to the sea, unless he knew the gem of the sea. (Asrarnameh, 2007/827)

Metaphor is from God "gem", it is similar to "sea" in that gem is extracted from the sea.

He said: O Lord, is not tonight my day?, rotating candles do not really burn. (Mantiq al-Tair, 2004/1252)

"Rotating candle" is an explicit metaphor for "sun", the words "burning and night" are similar to "candles" and reinforce it, which makes the explicit metaphor of the sign.

\section{Absolute explicit metaphor:}


Whenever, along with similar to, from the gentleness of the parties (similar and similar to), attributes or parallels are mentioned, it is called the explicit metaphor of the signified.

Fallen on the throne, which came the breast and the moon of both worlds. (Asrarnameh, 2007/286)

It is a metaphor of the Prophet (PBUH). The "Great Throne" is gentle (similar to), according to his Ascension, and the "world" is gentle (similar to).

Because an opponent saw the sheikh, the sheikh saw his stone in a smile

A fire of enthusiasm ignited in his life, a bloody flood fell on his eyelashes. (Mantiq al-Tair, 2004 / 1985-5)

The word "smiling" as an adjective or adverb for "stone" forms a single metaphor, because "stone" is related to "deception", they reinforce each other, which is called the metaphor of the sign. Now, according to the presence of the words related to the single metaphor and the metaphor in a bit, an absolute metaphor is made.

Eventually, because he was exhausted, before that, the fog was torn apart. (Mosibatnameh, 2007/2776)

"Part of the fog" or "part of the moon" is an explicit metaphor for the king's daughter, the existence of the word "horizon" makes the acceptance of the real word of the moon stronger and stronger, which is called the "metaphor of the horizon", but "going before it", due to the impatience of the lover, evokes the resemblance of the "king's daughter" that is, there are both similar and similar evidences and metaphors, and the single metaphor and the metaphor are used together, and these dual clues neutralize each other, which calls such artistic application "absolute metaphor."

\section{Metonymy:}

The word " metonymy " is placed in front of "truth." Truth is the first and most common meaning that comes to mind from a word. Metonymy is considered as one of the branches of rhetoric. "But in the science of expression, only the means of image and imagination are considered, which among the metonymy types, the interest of similarity is Metonymy, which is illustrative, illustrated and imaginative" (Shamisa, p. 31, 1992). Imagination and the metonymy help us to see the secrets of the real world, which are never seen and heard by the eyes and ears, and to make the invisible realities prominent and tangible with the help of the metonymy, that is, to be able to understand and transmit to others. Homayi in the book of Rhetoric Techniques and Literary Crafts, without elaborating on the metonymy and its types, in a brief explanation, considers the metonymy "use of a word other than the original meaning and the real subject as appropriate, and He says that occasion is called interest in the term of art and innovation. If the interest in the virtual and real sense is the interest of similarity, it is called metaphor, and if the interest is something other than similarity, it is called the metonymy messenger" (Homayi, 1992/252). They also "raise the metonymy argument in expression only in order to explain the metaphor, which is the most important metonymy type because in expression only imaginative and imaginative tools are considered and among the various types Metonymy, only metaphor is imaginative and imaginative "(Shamisa, 2005/21).

The metonymy definition says: "Whenever they use a word in a non-subject matter, that is, they bring the word and want to use it from a non-subject meaning, if there is a parallel to the lack of will of the real meaning, they call it metonymy" (Rajaei, 1961: 23). And he also says: "Every metonymy is inevitably one of two things, a symmetry, both verbal and spiritual, which occupies the listener's mind from the real meaning of interest and realizes the metonymy meaning. This symmetry is called the symmetry of the consumer. Another is that there must be an interest between the virtual meaning and the real meaning." (Rajaei, 1961/241) Example:

\section{Metonymy to container and contents:}

In this type, it is metonymy to mention the contents and will the container or vice versa, for example:

He asked for another wine and drank, He heard a ring in his ear (Mantiq al-Tair, 2007/1987)

"Wine ", meaning wine, is the container mentioned and means the "cup" and the contents.

\section{Metonymy for interest in totality and detail:}

In this type of metonymy implication of guarantee, the whole is used in the sense of part or the part can be used in the sense of whole. 
Whoever he was favored by the Prophet, Zebdash on the difference if he was an officer (Mantiq al-Tair, 2004/704)

The "crown" diadem is placed on the head, but instead the poet has mentioned the "sinciput" which is a part of the head, that is, he has mentioned the part and the whole will.

\section{Metonymy to interest cause and effect:}

That is, we mention the cause and will the cause or vice versa.

I'm leaving this noisy dustbin, Goodbye, O Sheikh of the world of farewell (Mantiq al-Tair, 2004/1591)

The concept of "sound" means a headache that is Metonymy to cause and cause love and is used in the concept of "suffering".

\section{Metonymy to interest Aliyat:}

That is, we mention the means of doing something, and the will itself, and the will to come into being.

The idolaters have grown out of your words, the companions are tired of your words (Mantiq alTair, 2004/570)

"Words" and "language" in the permissible meaning of speech, Attar has used this word as metonymy for the interest of the Aliyat, that is, the pagans have been freed from your annoying words.

\section{Metonymy to interest in the past:}

Naming something by name or adjective that thing has been in the past. For example, we mention "soil" and will "man".

Blessed is the pure human being, the one who gave life and human faith (Mantiq al-Tair, 2004/1)

" Bless" at the beginning of the verse is a quasi-sentence that has the meaning of admiration, which with the word "Bless" in combination with " make alive" has a full connotation that has made the verse more and more artistic. The word "soil" is Metonymy to interest in the past in the human concept, which is imaginative and thought-provoking and, in terms of concept, informs man of his past and...

Irony:

The word means "to speak in secret so that the meaning is not explicit." (Moin, 2009, the word irony) and in literary terms, "a word whose true meaning and institution cannot be denied; But according to the present and in the relation and occasion of time and place and subject and article, another meaning of it is understood "(Servatian, 2004: 422). And in the term "composition or sentence which does not mean the speaker its apparent meaning; But there is no symmetrical counterpart that draws us from the outward meaning to the inward meaning. So the irony of mentioning one thing and receiving another is the words and the apparent meaning, Makni to, and in the meaning of the meaning of Makni to (Shamisa, 2005: 143).

Irony is one of the elements of illustration and is considered as an artistic tool. "Irony is also reaching from one level to another, and it creates a connection between the present and the absent. It has an artistic and literary aspect." (Shamisa, 1991: 236). Where satire cannot be used, irony is the best way to express militant thoughts and ideas. The conflict between reason and love in literary texts has expanded the use of irony in such works. Using this rhetorical element, Attar, in indirect ways, expresses his thoughts and perceptions of inspiration in order to create imagination and delight in the reader in a covert and ironic way, this concealment in the expression of thought and escape from the ordinary logic of speech, Attar mastery of the words of the language and complete familiarity with the culture of the past. Because, it is clear that the poet does not want to use only the explicit accent and words to express and induce his conscience. Because it destroys the pleasure of searching. Therefore, Attar expresses some of his meanings and concepts in a cover of complex words and expresses them indirectly and ironically in order to make his words effective and interesting. Like the:

\section{Irony to noun:}

Eight garden ceiling lights, Night of Ascension in the Night of Lights (Asrarnameh, / 263)

The irony is of four elements and eight gardens, the poet means the irony of eight paradises.

He trapped a spider in wisdom, He calmed the heart of the world in him (Mantiq al-Tair, 2004: B16) 
Heart of the world: It is an irony to the Holy Prophet (PBUH).

\section{Irony of adjective:}

The earth itself is dust with sorrow, the sky is in mourning (Ibid: p. 118/1947)

It is an irony to falling on the ground, which Attar has used to make the Salek miserable in the grief of not losing the truth.

Wisdom obeyed the city through tears, He revived both life and faith (Mantiq al-Tair, 2004: B12)

Obeyed: It is an irony to obedience and submission. In this hemistich, the intellect submits and obeys in the face of religious rules and important issues that it cannot reach or accept.

\section{Irony of the verb:}

So said that dear to your religion, who gave this loan until the right to offer it (Asrarnameh, 2007/687)

The irony is that, man, you were born to carry the burden of trust, I am afraid that you will not be able to endure in this way and lose your life.

He laid his throne on the water, He gave life to the people of soil (Mantiq al-Tair, 2004/2).

\section{Conclusion}

The study of Attar Neyshabouri's Masnavi shows that the frequency of illustration and content creation with religious proclamation is higher in these works, which is directly related to his thoughts, ideas and beliefs as a Muslim mystic. Comparing all the names of science with each other shows that the most images belongs to the word of God and the most content belongs to the name of science Muhammad (PBUH). The reason for the depiction with the word God is undoubtedly rooted in Attar's firm and heavenly beliefs and his true love for the origin of the universe. The reason for the high frequency of creating content with the name of the knowledge of Hazrat Mohammad (PBUH) is also Attar's devotion to that Hazrat. Attar's purpose in using proclamation to illustrate and create content is to explain abstract, mystical and intellectual meanings to the ordinary classes, the general public and the novice seekers, which has made it easy to understand and convey his thoughts. According to the research data, it can be concluded: 1- Attar Neyshabouri, although he is known among the speakers of critics as a mystic and poet, However, it must be admitted that his language has a special place in terms of illustration and creation of poetic spaces as well as the use of imaginary forms.

2- Since the sheikh has manifested the perfection of his thought by illustrating and using imaginary forms in his poems, it is not possible to know him and his thoughts without knowing these beautiful images that have a special grace and charm.

3- Although Attar Neyshabouri, like Rumi, is not bound by speech, voice and speech, and his purpose in composing poetry is to express all his inner reflections and mystical and moral principles, but he has not neglected the arrangement of words. He is a great poet in terms of creating diversity in the fields of poetic imagination and also in terms of illustrations. What increases Attar's art and his power in composing his poems is the expression of mystical and difficult experiences, in a tangible way and through these visual expressions which, in turn, objectifies abstract matters and abstract concepts.

4- The language and style of expression of Attar Neyshabouri The illustration about mystical concepts is based on simplicity and has used unaffected words, his soft language and pleasant speech, which comes from a burnt heart and loves and is familiar with knowledge, better induces mystical truths in the heart of the audience.

5- Attar Neyshabouri has used the method of "brevity" in expressing the sub-anecdotes of his poems so that the reader will understand it better when the article is shortened and the result will not be lost in the margins of the articles and this is the reason why Attar's language has a superiority and miracle in expressing poems over other poets.

6- In addition to proposing mystical and moral concepts in his poems, Attar Neyshabouri has also paid attention to social issues such as the tyranny and injustice of the rulers, the behavior of the tyrants, the blackmail of the rulers and the blindly prejudices of a sect, and he often teaches excellent and moral examples such as foresight, generosity, instructiveness, trust and submission to the truth. 


\section{References}

Attar, F. (1994). Mosibatnameh, edited by Zavar Publications, Tehran.

Attar, F. (2010). Elahinameh, edited by H, Majdabadi, Zavar Publications, Tehran.

Attar, F. (2009). Mantiq al-Tair, edited by M, Shafiee Kadkani, Sokhan Publications, Tehran.

Attar, M. I. I. (2004). Mantiq al-Tair, twentieth edition, edited by Sadegh Goharin, scientific and cultural publication, Tehran.

Attar, M. I. I. (2013). Mantiq al-Tair, ninth edition, edited by Shafi'i Kadkani, Tehran.

Braheni, R. (1965). A Night of Noon and the System of a Prose Life, Tala Dar Mes Publications, Tehran.

Fotouhi, M. (2006). Picture Rhetoric, Sokhan Publications, Tehran.

Fotouhi, M. (2010). Picture Rhetoric, Second Edition, Sokhan Publications, Tehran.

Hawks, T. (1998). Metaphor, translated by Farzaneh Taheri, third edition, Markaz Publishing, Tehran.

Homayi, J. (1992). Rhetoric Techniques and Literary Crafts, Third Edition, Homa Publishing, Tehran.

Islami Nodooshan, M. A. (2004). From Rudaki to Bahar, Naghmeh Zandegi, Nashrgovia

Jahez, A. U. (1999). Al-Bayyan wa Al-Tabiyin, Bita Publishing, Dar Al-Kitab Al-Almiyeh.

Jung, C. G. (1993). Tourism, translated by Jalal Sattari, Nashratus, Tehran.

Kazazi, M. J. (1989). Bayan, Markaz Publishing, Tehran.

Moin, M. (2009). Persian Culture, 26th Edition, Amirkabir Publishing, Tehran.

Rajaei, M. K. (2000). Moallem al-Balaghah, fifth edition, published by Shiraz University.

Shafiee Kadkani, M. R. (1979). Poetry Music, Toos Publications, Tehran.

Shafiee Kadkani, M. R. (1987). Imagination in Persian Poetry, Agah Publications, Tehran.

Shafiee Kadkani, M. R. (1996). Imagination in Persian Poetry, Agah Publications, sixth edition, Tehran.

Shafiee Kadkani, M. R. (1999). Mantiq al-Tair, Sokhan Publications, Tehran.

Shafiee Kadkani, M. R. (2001). Persian Poetry Periods, Third Edition, Sokhan Publications, Tehran.

Shafiee Kadkani, M. R. (2004). Mantiq al-Tair, Sokhan Publications, Tehran.

Shafiee Kadkani, M. R. (2007). Asrarnameh, third edition, Sokhan Publications, Tehran,

Shafiee Kadkani, M. R. (2007). Misibnameh, first edition, Sokhan Publications, Tehran.

Shafiee Kadkani, M. R. (2008). Elahinameh, Sokhan Publications, Tehran.

Shamisa, S. (1991). A Look at Sepehri, Morvarid Publications, Tehran.

Shamisa, S. (1992). A New Look at the Innovative, Ferdows Publications, Tehran. 
Shamisa, S. (2005). Expression and Meanings, Second Edition, Mitra Publishing, Tehran.

Skelton, R. (1996). Poetry Story, translated by Mehrangiz Ouhadi, first edition, Mitra Publications, Tehran.

Thorotian, B. (2004). Expression in Persian Poetry, Barg Publications, Tehran.

Zarrinkoob, A. (1988). Search in Iranian Sufism, published by Amir Kabir, Tehran. 